\section{Section Editor}

Mitchell S.V. Elkind, MD, MS
Alexander Lehn, MD George Mellick, PhD Richard Boyle, FRACP

Address correspondence and reprint requests to Dr. Alexander Lehn, Department of Neurology, Princess Alexandra Hospital, 199 Ipswich Road, Woolloongabba QLD 4102, Australia alex_lehn@health.qld.gov.au

\title{
Teaching NeuroImages: Neuroferritinopathy
}

\section{Figure Brain imaging}
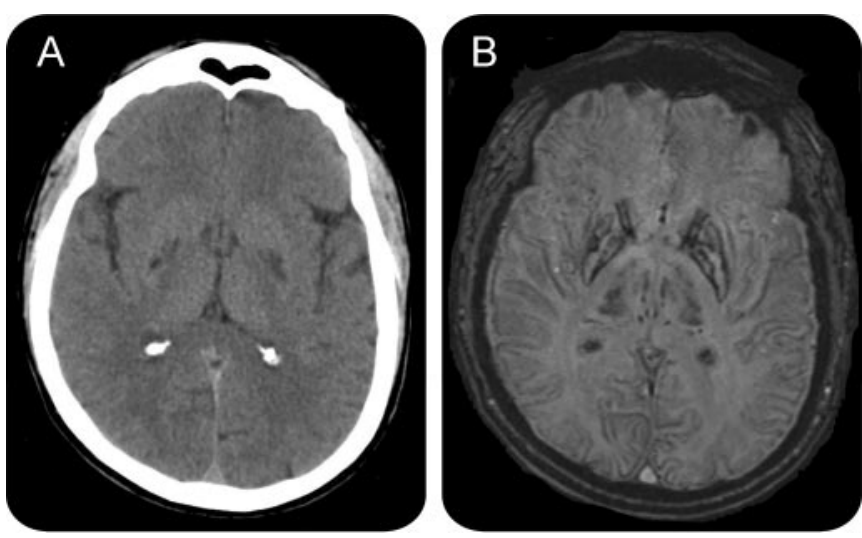

(A) Cavitation of the basal ganglia on axial CT scan of the brain. (B) Axial susceptibility-weighted MRI shows iron deposition in basal ganglia.

A 51-year-old music teacher presented with difficulty playing his flute and mild dysarthria related to impaired tongue movements. Over the subsequent 11 years, he developed fluctuating chorea and bradykinesis, stereotypic foot tapping, and a grossly unsteady gait, resulting in him becoming chairbound 9 years later. He further developed profound dysarthria and dysphagia. Cognitive impairment was not observed. There is a strong family history, with the patient's father and 3 siblings also affected by this movement disorder.

CT scanning showed cavitation of the basal ganglia while susceptibility-weighted MRI demonstrated iron accumulation in basal ganglia, cerebellum, and cerebral cortex (figure). DNA analysis revealed the common 460InsA mutation for neuroferritinopathy, an autosomal dominantly transmitted condition caused by mutation of the ferritin light chain gene. ${ }^{1}$

\section{AUTHOR CONTRIBUTIONS}

Dr. Lehn: drafting/revising the manuscript, analysis or interpretation of data. Dr. Mellick: drafting/revising the manuscript, study concept or design, analysis or interpretation of data, acquisition of data, study supervision. Dr. Boyle: drafting/revising the manuscript.

\section{REFERENCE}

1. Curtis AR, Fey C, Morris CM, et al. Mutation in the gene encoding ferritin light polypeptide causes dominant adult-onset basal ganglia disease. Nat Genet 2001; 28:350-354. 


\title{
Neurology
}

\author{
Teaching NeuroImages: Neuroferritinopathy \\ Alexander Lehn, George Mellick and Richard Boyle \\ Neurology 2011;77; e107 \\ DOI 10.1212/WNL.0b013e318236492c
}

This information is current as of October 31, 2011

\section{Updated Information \& Services}

\section{References}

Citations

\section{Subspecialty Collections}

Permissions \& Licensing

\section{Reprints}

including high resolution figures, can be found at: http://n.neurology.org/content/77/18/e107.full

This article cites 1 articles, 0 of which you can access for free at: http://n.neurology.org/content/77/18/e107.full\#ref-list-1

This article has been cited by 1 HighWire-hosted articles: http://n.neurology.org/content/77/18/e107.full\#\#otherarticles

This article, along with others on similar topics, appears in the following collection(s):

Basal ganglia

http://n.neurology.org/cgi/collection/basal_ganglia

\section{Chorea}

http://n.neurology.org/cgi/collection/chorea

Dystonia

http://n.neurology.org/cgi/collection/dystonia

Gait disorders/ataxia

http://n.neurology.org/cgi/collection/gait_disorders_ataxia

Parkinson's disease/Parkinsonism

http://n.neurology.org/cgi/collection/parkinsons_disease_parkinsonism

Information about reproducing this article in parts (figures,tables) or in its entirety can be found online at:

http://www.neurology.org/about/about_the_journal\#permissions

Information about ordering reprints can be found online:

http://n.neurology.org/subscribers/advertise

Neurology ${ }^{\circledR}$ is the official journal of the American Academy of Neurology. Published continuously since 1951, it is now a weekly with 48 issues per year. Copyright Copyright (? 2011 by AAN Enterprises, Inc.. All rights reserved. Print ISSN: 0028-3878. Online ISSN: 1526-632X.

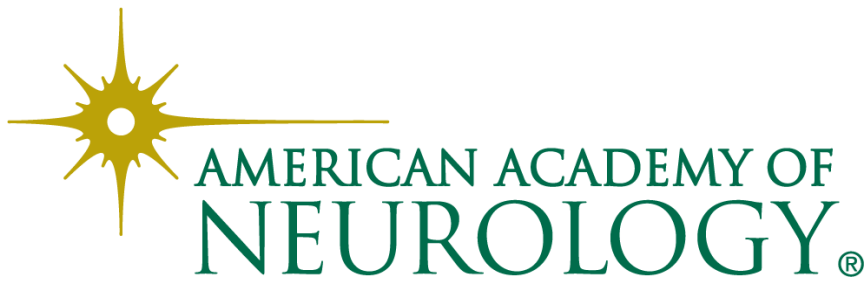

